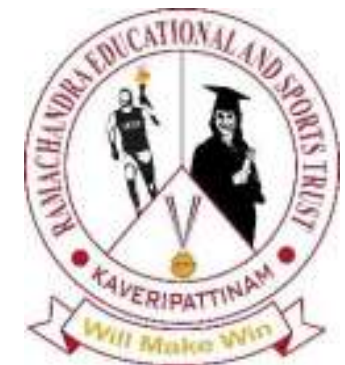

\author{
Recenttrendsin ManagementandCommerce \\ Vol:2(2),2021 \\ REST Publisher \\ ISBN:978-81-936097-6-7
}

Website:http://restpublisher.com/book-series/rmc/

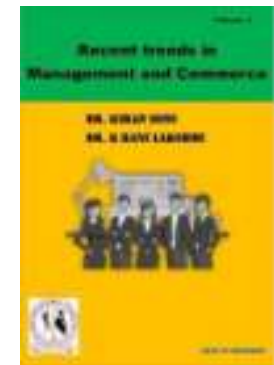

\title{
"A Comparative Study about the work environment pre and post covid of the employees working in textile industry with respect to Chennai city".
}

\author{
Ms, Sambamurthi Murthy, V.Sarvasree Rajalakshmi Jain \\ Shri Shankarlal Sundarbai Shasun Jain College for Women in Chennai, Tamilnadu, India. \\ Email: veerpadmajain@gmail.com
}

\begin{abstract}
The textile trade/ business in India habitually, after agriculture, is the only trade/ business that has produced huge employment opportunities for both skilled and unskilled labour The textile trade/ business continues to be the second-largest employment producing sector in India. The Covid situation has affected many indivials and business. Textile business is no exception to it. All the people realeted to this textile industry both externally and internally have been affected immensely. This research is done to have a comparative study on the work environment of textile industry employees pre and post covid.
\end{abstract}

\section{Introduction}

The prevailing covid situation has caused drastic changes in the livelihood of every person,. Each and every sector has been affected in its own way. Due to lockdown almost all the industries or Corporates lacked revenues.Similarly, textile industry has faced various challenges and losses during these pandemic situations. Both employer and employee have faced various difficulties. Employees access various problems such as reduction in salary, retention etc., These issues have a direct impact on their livelihood and make create financial crisis to them. This is, a comparative study about the changes that many employees of textile industry have gone through in this pre and post covid situation. This study is, all about the perks, stress, work timing, salary, customer, and opportunity changes pre and post covid.Statement of the problem: In this pandemic situation employee are the salary person face various type of problems. Out routes these kinds of problems and the areas that are directly or indirectly affected due to these problems. This project States the difficulties faced by the employees and suggest some alternative to overcome it.Objectives:To compare the monetary and non-monetary perks received by the employees pre and post covid. To Analyze the degree of variance affecting the employee, with respect to their work environment.To analyze the alternative livelihood method adopted by textile sector employee. To detect the extent of satisfaction among employees for Revival strategies taken by the employer.Limitations:The sample size may not represent the entire population of the employees. The validity and reliability of the data depends on the truthfulness of the respondents. Though the data is, not refrained to any constraint it does not cover all the employees outside Chennai The problems may vary from place to place thus studying a particular area, Chennai, may not conclude the problems of the employees. The Study may not cover all the problems faced by textile industry employees. The results are based on only a sample size of 500 respondents.Research methodology:According to Kothari (2004), research Methodology is, a method to analytically explain the research problem. It may be described as a science of analysis how research is, done systematically. In it we investigate the various stages that are generally implemented by a scholar in studying his problem of research in conjunction with the reason behind them.Research Design:Research design is, the blue print for empirical research work that guides the research in a scientific way towards the achievement of the objectives. This survey has supported the researcher to find the various types of problems faced by the employees of textile industry. The research is, designed in the Descriptive model as it includes survey through Structured Schedule to collect the data of survey. The primary data is, collected from the textile industry employees who work as well stay within Chennai. The research is done based on a Structured Schedule which includes 21 Questions of Multiple choice, scaling questions and ranking questions. PopulationThe targeted population of the study is, more than 500 respondants who are the employees of various textile industry in Chennai. A research problem is, generally a large collection of individual or objects that is, the main focus of a scientific query.

\section{Review of Literature}

Walton (1973) has stated that the important conceptual areas have to be identified via, adequate and fair compensation, safe and healthy working conditions, development of human competencies, growth and security, social integration of work life.Dela motte and Walker (1974) have determined that intensity have been made in the humanization of work which includes the need to protect the worker from hazards to health and safety and securityKatz ell et. Al (1975) have noted that an employee may enjoy a high quality of working life when he has optimistic feelings towards his job and its future prospects, to stay on the job and perform well. A report by QWL taskforce in George Manson University in Virginia, USA apprise the quality of their employees work lives and identified that the major source of stress in work and the aspects of satisfaction / dissatisfaction of 
Sambamurthi Murthy et.al/Recent Trends in Management and Commerce Vol:2(2),2021:87-91

work affected the QWL of their employees.Glasier (1976) has stated that quality of work life implies job security, good working. conditions, adequate, and fair compensation and more even equal employment opportunity all together.

\section{Data Analysis and Interpretation}

Introduction This chapter deals with the interpretation of various analyses used on the basis of the Respondents' views, collected through the scheduled questionnaire. This study tries to analyse the variations in the benefits provided and the problems faced by the employees of textile industry.Comparison between Non-monetary benefits provided before and after covid:Non-Monetary benefits are the benefits that are in terms other than money. These benefits are provided to employees as a encouragement factor. This comparison is made to analyses the level of non-monetary benefits provided to the respondents before and after covid.

TABLE 1.Comparison between non-monetary benefits

Before Covid

After Covid

\begin{tabular}{|l|l|l|l|l|}
\hline & Frequency & Percent & Frequency & Percent \\
\hline Boxing day rest & 106 & 21.2 & 84 & 16.8 \\
\hline Health care & 256 & 51.2 & 129 & 25.8 \\
\hline Free lunch & 138 & 27.6 & 39 & 7.8 \\
\hline None & 0 & 0 & 248 & 49.6 \\
\hline Total & 500 & 100 & 500 & 100 \\
\hline
\end{tabular}

(Source: Primary data)

From the above table it can be conclude that all the non-monetary benefits provided before covid have been cut-off after covid, esp providing free lunch. The percentage of providing free lunch have come down from 27.6 to 7.8. Many respondents have stated that there is no non-monetary benefits provide after covid.

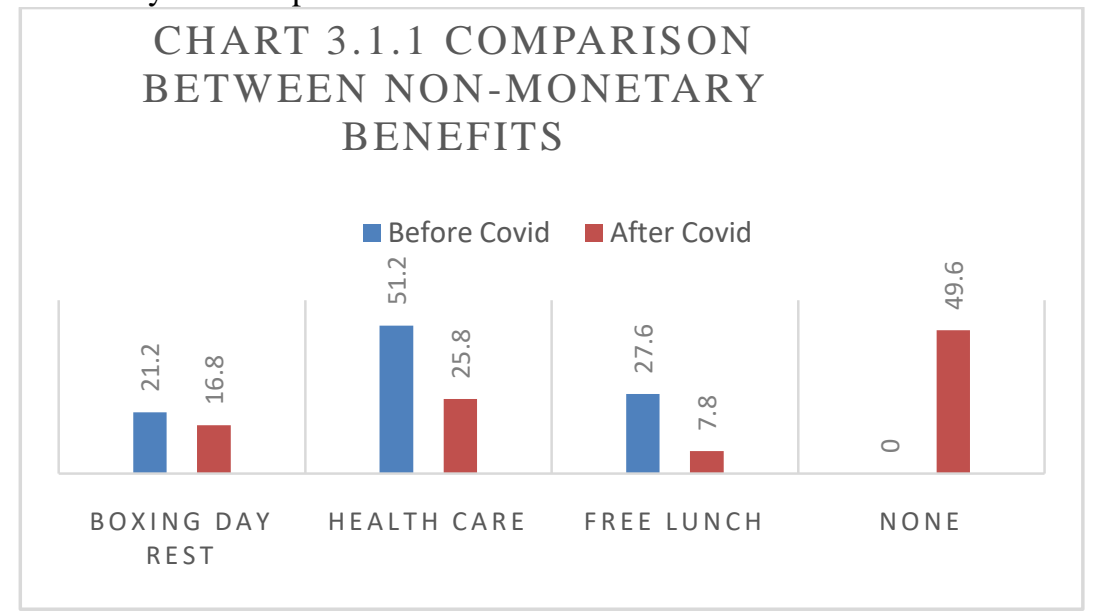

FIGURE 1. Comparison between non-monetary benefits

Alternative method taken up to compensate the loss:Due the pandemic the respondents were expected to take up some alternative method to compensate the crises.

TABLE 2.Alternative method taken up to compensate the loss

\begin{tabular}{|l|r|r|}
\hline & Frequency & Percent \\
\hline Alternative Job & 185 & 37 \\
\hline Self business & 144 & 28.8 \\
\hline $\begin{array}{l}\text { Additional working member in the } \\
\text { family }\end{array}$ & 170 & 34 \\
\hline Total & 500 & 100 \\
\hline
\end{tabular}

(Source: Primary data) 
Sambamurthi Murthy et.al/Recent Trends in Management and Commerce Vol:2(2),2021:87-91

The above table clearly shows that many respondents have opted Alternative job to compensated the loss during the pandemic time.

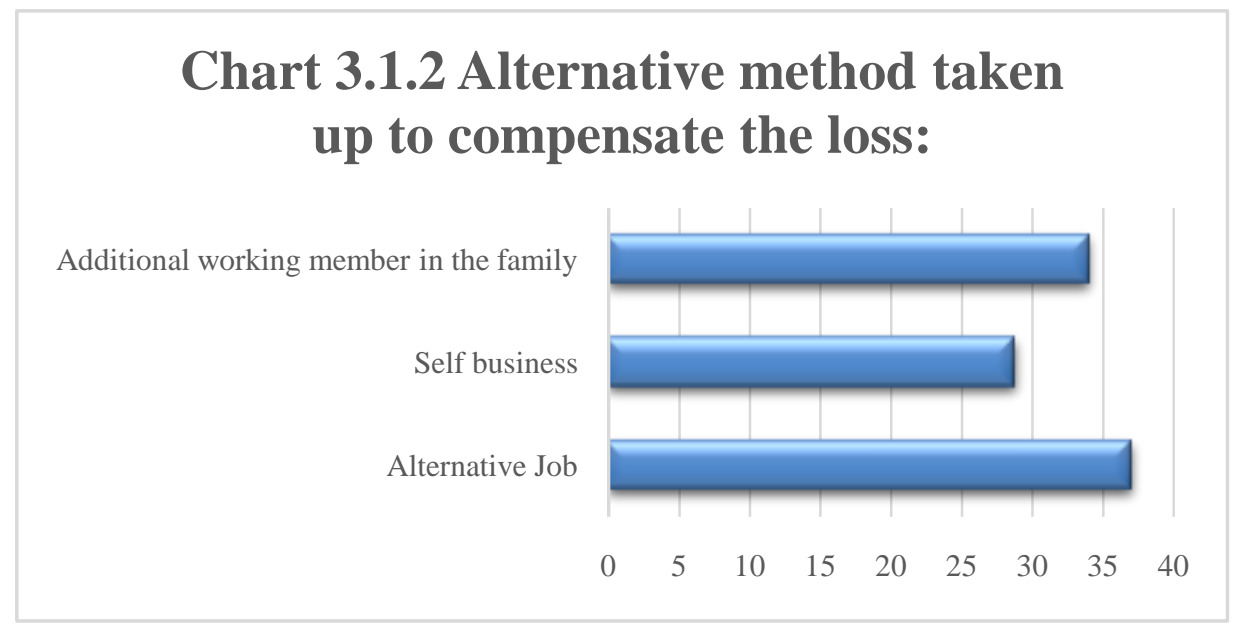

FIGURE 2. Alternative method taken up to compensate the loss

Revival Strategies:Revival Strategies are the safety measures taken by the employer to protect the employee.

TABLE 3. Are there any Revival strategies taken by your employer?

\begin{tabular}{|c|c|c|}
\hline & Frequency & Percent \\
\hline Yes & 61 & 12.2 \\
\hline No & 438 & 87.6 \\
\hline Total & 500 & 100 \\
\hline
\end{tabular}

(Source: Primary data)

The above table clearly shows that majority of the respondents nearly $87.6 \%$ have stated that no revival strategies were taken by the employer.

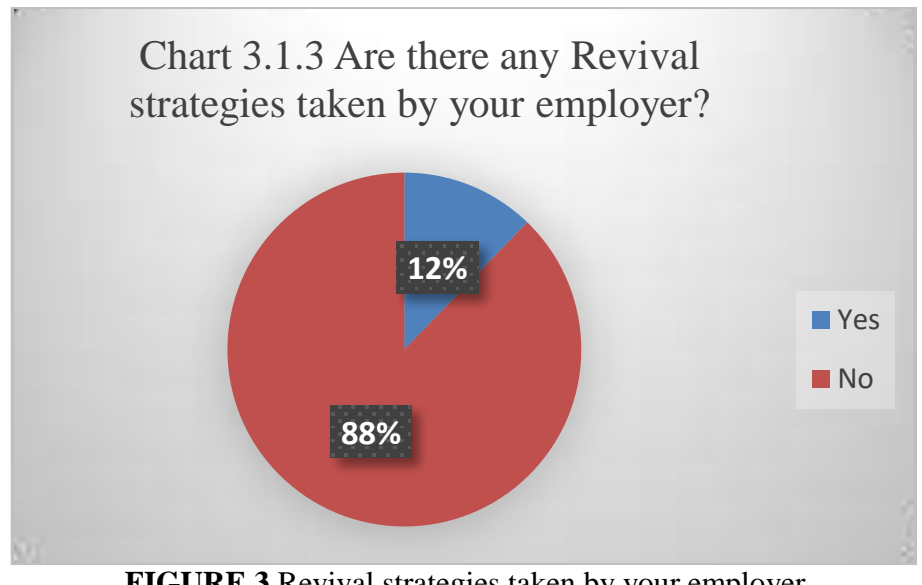

FIGURE 3.Revival strategies taken by your employer

Association between reason for retention and degree of variance affecting the employee with respect to their work environment

The Chi-Square test is used to analyse the relationship between two variables and find whether the two variables are independent or not. chi square test is used to find the association between reason for retention and degree of variance affecting the employee with respect to their work environmentHo: There is no association between the reason for retention and degree of variance affecting the employee with respect to their work environmentH1: There is an association between the reason for retention and degree of variance affecting the employee with respect to their work environment 
CHI-SQUARE TEST

TABLE 4. Chi-Square Test

\begin{tabular}{|c|c|c|c|}
\hline Reason for retention & Value & df & $\begin{array}{l}\text { Asymp. Sig. (2- } \\
\text { sided) }\end{array}$ \\
\hline Pearson Chi-Square & $12.948^{\mathrm{a}}$ & 1 & $<0.001$ \\
\hline Continuity Correction & 10.230 & 1 & .001 \\
\hline Likelihood Ratio & 14.770 & 1 & .000 \\
\hline \multicolumn{4}{|l|}{ Fisher's Exact Test } \\
\hline Linear-by-Linear Association & 12.896 & 1 & .000 \\
\hline $\mathrm{N}$ of Valid Cases & 249 & & \\
\hline \multicolumn{4}{|c|}{$\begin{array}{l}\text { a. } 2 \text { cells }(50.0 \%) \text { have expected count less than } 5 \text {. The minimum expected count is } \\
2.50 \text {. }\end{array}$} \\
\hline \multicolumn{4}{|l|}{ b. Computed only for a $2 \times 2$ table } \\
\hline
\end{tabular}

(Source: Computed data)

InferenceFrom the above table it is inferred that the Pearson Chi-Square is 12.948and the significance value is $<0.05$ indicating there is a significant association between the reason for retention and degree of variance affecting the employee with respect to their work environment.Association between alternative methods take up to compensate loss and alternative livelihood method adopted by textile sectorThe Chi-Square test is used to analyse the relationship between two variables and find whether the two variables are independent or not. chi square test is used to find the association between alternative methods take up to compensate loss and alternative livelihood method adopted by textile sector.There is no association between alternative methods take up to compensate loss and alternative livelihood method adopted by textile sector.There is an association between alternative methods take up to compensate loss and alternative livelihood method adopted by textile sector.

CHI-SQUARE TEST

TABLE 5. chi-square test

\begin{tabular}{|l|r|r|r|}
\hline $\begin{array}{l}\text { Alternative livelihood method } \\
\text { adopted by textile sector }\end{array}$ & Value & df & $\begin{array}{c}\text { Asymp. Sig. (2- } \\
\text { sided) }\end{array}$ \\
\hline Pearson Chi-Square & $190.804^{\mathrm{a}}$ & 4 & $<0.001$ \\
\hline Likelihood Ratio & 222.891 & 4 & .000 \\
\hline Linear-by-Linear Association & 158.957 & 1 & .000 \\
\hline N of Valid Cases & 499 & & \\
\hline $\begin{array}{l}\text { a. 0 cells }(0.0 \%) \text { have expected count less than 5. The minimum expected count is } \\
\text { 41.84. }\end{array}$
\end{tabular}

(Source: Computed data)

InferenceFrom the above table it is inferred that the Pearson Chi-Square is 190.804and the significance value is <0.05 indicating there is a significant association between alternative methods take up to compensate loss and alternative livelihood method adopted by textile sector.Association between degree of the satisfaction level with respect to revival strategyThe ChiSquare test is used to analyse the relationship between two variables and find whether the two variables are independent or not. chi square test is used to find the association between degree of the satisfaction level with respect to revival strategy.There is no association between degree of the satisfaction level with respect to revival strategy.There is an association between degree of the satisfaction level with respect to revival strategy.

TABLE 6. chi-square test

\begin{tabular}{|l|r|r|r|}
\hline Safety ensured by the employer & \multicolumn{1}{|c|}{ Value } & Asymp. Sig. (2-sided) \\
\hline Pearson Chi-Square & $0.028^{\mathrm{a}}$ & 1 & 0.867 \\
\hline Continuity Correction & 0.000 & 1 & 1.000 \\
\hline Likelihood Ratio & 0.027 & 1 & .870 \\
\hline Fisher's Exact Test & & 1 & .867 \\
\hline Linear-by-Linear Association & 499 & & \\
\hline N of Valid Cases & & \\
\hline a. 1 cells (25.0\%) have expected count less than 5. The minimum expected count is .86. \\
\hline b. Computed only for a 2x2 table
\end{tabular}

InferenceFrom the above table it is inferred that the Pearson Chi-Square is 0.028 and the significance value is $>0.05$ indicating there no significant association between degree of the satisfaction level with respect to revival strategy. 


\section{Findings, Suggestion and Conclusion}

Findings of the study:The study shows that all the non-monetary benefits provided before covid have been cut-off after covid, esp. providing free lunch. The percentage of providing free lunch have come down from 27.6 to 7.8. Many respondents have tated that there is no non-monetary benefits provide after covid.Respondents have opted Alternative job to compensated the loss during the pandemic time.The respondents nearly $87.6 \%$ have stated that no revival strategies were taken by the employer.There is a significant association between the reason for retention and degree of variance affecting the employee with respect to their work environment. There is a significant association between alternative methods take up to compensate loss and alternative livelihood method adopted by textile sector.There no significant association between degree of the satisfaction level with respect to revival strategySuggestions:The employer should ensure the safety of the employee.Many alternatives should be chosen by the employer to ensure the satisfaction level of the employee.An employee should always have a $2^{\text {nd }}$ source of income to meet the unpredicted situation.

\section{Conclusion}

Covid is, a unpredictable occurrence that nature gave to test people's stability and unity. Every person should be aware of these kinds of occurrences and be prepare to face it.On the text of Textile Industry employer, they should ensure the safety and satisfaction level of their employee to maintain their standards. Regular termination or resignation will after the Fame of the company.Even the employers should take up their job seriously and choose a right job for them. Many people work in these company for a short period until they a better paid job. Finally, I conclude this Covidhas drastically altered many people's lives. The only way to overcome it is, to FACE IT. 